\title{
Transitions: Studies in Religion and the Age of Enlightenment (Editorial Introduction)
}

\section{Samara Cahill \\ Nanyang Technological University, Singapore}

$S$

tudies in Religion and the Enlightenment (SRE) is the online continuation of the print journal Religion in the Age of Enlightenment (RAE), formerly published by AMS

Press. In 2017, $R A E$ was abruptly forced to halt production, along with several other eighteenth-century journals, when AMS Editor-in-Chief Gabriel Hornstein passed away. Hornstein —or "Gabe," as many knew him—had been a generous patron of eighteenthcentury scholarship for decades. Gabe's unique brand of patronage is irreplaceable and his passing sent shock waves through the eighteenth-century studies community.

The effects of Gabe's loss are still being felt. Not only has the community lost a beloved friend and patron, but many journals have found it difficult to find a new home. From its first year, $R A E$ responded to disaster-like many other journals-with fortitude and creativity. The genesis of $R A E$ came to fruition through serendipitous moments of interpersonal connection, as the senior board members describe below. In the sociable web of global eighteenth-century studies, it has now found a home as Studies in Religion and the Enlightenment. SRE benefits from the support of two institutions that have stepped forward with time, manpower, and other resources to ensure that its vision continues: the Brigham Young University Faculty Publishing Service and Nanyang Technological University, Singapore. I like to think that this digital resurrection is a moment of change in continuity.

The 2009 South Central Society for Eighteenth-Century Studies (SCSECS) conference in Corpus Christi, Texas, crystallized what Religion in the Age of Enlightenment meant to many of us. The conference venue had shifted abruptly from Galveston to Corpus Christi due to the damage inflicted by Hurricane Ike in September 2008. It took five years for SCSECS to return to Galveston in 2014. Yet somehow the conference in Corpus Christi was, as the SCSECS website called it, truly "effervescent"-a dynamic and bubbly celebration of fellowship in the midst of forces beyond human control.

I first met the RAE editorial leadership_Editor Brett McInelly and Book Review Editor Kathryn Duncan - in Corpus Christi. Brett and Kathryn were fortuitously on registration duty when I arrived and they immediately made me feel at home. Here were two established scholars who weren't above investing their time and administrative labor for the good of their organization. Nor were they above chatting with an unseasoned graduate student. Fliers for the first volume of Religion in the Age of Enlightenment were on display at the registration table and I remember thinking how lovely it would be to be published in such a unique journal, one bringing an unusual and much-needed perspective to eighteenth-century studies. I couldn't know it then-the 2008 financial crisis made it unlikely that I would be hired as a tenure-track faculty member - but that morning at the registration table with Brett and Kathryn set the tone for my professional career. They were, and are, incredibly generous mentors who modelled not only valuable editorial work, but also the can-do attitude of undertaking unglamorous administrative service in the aftermath of a natural disaster. Brett and Kathryn were there at the registration desk that morning to contribute to all levels of the eighteenth-century community, from graduate students to Keynote Speakers. I have always admired them and endeavoured to follow their examples.

SCSECS is meeting in Dallas in 2019 and it will mark the ten-year anniversary of that meeting with Brett and Kathryn - and of meeting other mentors associated with Religion in the Age of Enlightenment, particularly Kevin Cope, Baerbel Czennia, and other SCSECS 
board members. Many long-time SCSECS members were also associated with Religion in the Age of Enlightenment and they pulled together, just like after Hurricane Ike, when they heard the devastating news of the death of Gabe Hornstein and the collapse of AMS Press.

Continuing his work is a way of honouring Gabe's memory and of remembering his benevolent influence on decades of eighteenth-century scholarship. Those of us who never knew him nevertheless benefitted from his love for, and support of, the profession and its people. Like Gabe, many of the board members of Religion in the Age of Enlightenment made a conscious commitment to guiding early career professionals, as Paul E. Kerry mentions below. As a recipient of that commitment, I can say with certainty that my career would never have survived without scholars - many of whom are on the SRE boardintervening when disaster threatened. I am grateful to be able to work with Brett, Brigham Young University’s Faculty Publishing Service, Nanyang Technological University’s Office of Information, Knowledge and Library Services (OIKLS), and the SRE board to continue the legacy of $R A E$ in the digital environment. Gabe's passing was a disaster for all of us but, like Hurricane Ike, devastation can strengthen a community. The eighteenth-century community is adept at responding to crisis, reaching out to old allies and new friends, and becoming stronger, richer, and more diverse in the midst of hardship. Studies in Religion and the Enlightenment will continue the legacy of Gabe and of Religion in the Age of Enlightenment: editorial commitment, administrative effort, and an investment in diverse perspectives. The spirit of Corpus Christi lives and it welcomes all perspectives on religion in the "long" eighteenth century (1660-1832).

Transitions and adaptations are difficult moments requiring decisions to be made about what can stay and what must go. Happily, in the midst of disaster, the RAE and SRE boards have worked to ensure that Gabe's vision, Brett's vision, and the place of religion in eighteenth-century studies continue in a new online environment. With our inaugural issue, the $S R E$ editorial team wanted to emphasize the deep continuities in this moment of transition. Senior board members of $R A E$ have graciously shared their memories of Gabe Hornstein's patronage, $R A E$ 's development, and their thoughts about why the transition to $S R E$ is a lasting expression of $R A E$ 's vision. Please read further to share the memories and different perspectives of Kathryn Duncan, Paul E. Kerry, Kevin Cope, and Brett McInelly.

Our inaugural issue is dedicated to the memories of Gabe Hornstein, Diane Long Hoeveler, John Richardson, and Bob Tennant. They were generous and collegial members of the eighteenth-century community and brightened the lives of many scholars involved in the creation of SRE. They will be missed.

\title{
Memories of Religion in the Age of Enlightenment
}

\author{
Kathryn Duncan, Saint Leo University \\ Book Review Editor, Religion in the Age of Enlightenment (2009-2014)
}

Religion in the Age of Enlightenment had long roots at AMS Press. The seeds were planted in 2005 when I edited a special edition of an AMS journal called Symbolism. The section that I edited had the title "Religion in the Age of Reason" and included essays exploring the largely overlooked but extremely important topic of religion in understanding the Enlightenment. Gabe Hornstein, president of AMS, asked me to take the essays from that special section along with new essays and publish a book called Religion in the Age of Reason: A Transatlantic Study of the Long Eighteenth Century, which AMS published in 2009. Again, 
Gabe felt there was more to be said. At the time, as the mother of a young child and with a heavy teaching load, I agreed, but said I couldn't be the one to help say it.

Fortunately, I knew just the person: Brett McInelly. I'd known Brett through the South Central Society for Eighteenth-Century Studies for several years, knew of his scholarship in Methodism, and was confident that he would be the best editor Gabe could find to continue this important work. Brett agreed, asking me to serve as his book review editor, which I did through 2014 until Brett and I asked Samara Cahill to take over those duties, which she did with great efficiency and aplomb.

Sadly, Gabe's death resulted in the closing of AMS Press. Gabe was a great friend to eighteenth-century studies, and both he and his contributions to the discipline are missed. Yet $R A E$ will continue under a new title and with Brett and Sam's tutelage. The journal finally will have an online presence that will give more scholars worldwide access. Those of us who have studied the eighteenth century from the perspective of religion know that while this time period is known for its secularism, the works most published were religious tracts and sermons. If anyone wishes to understand this vital, early-modern period, he/she must include the perspective of religion. Studies in Religion and the Enlightenment will serve that role. I am pleased and proud to continue to be involved with this work as a board member.

\title{
Paul E. Kerry
}

\section{Brigham Young University Visiting Fellow, Centre for Theology, University of Oxford}

I was a member of the editorial board for Religion in the Age of Enlightenment, and attracted by its mission to analyze the intellectually complex relationship between Enlightenment and religious discourses in the long eighteenth century. My role was to foster strong contributions from early career scholars and seek articles that engaged with topics and sources beyond the Anglophone world. This was enjoyable and useful service. It was a pleasure to help researchers new to the profession and benefitted and strengthened RAE. My most fulfilling experience of working with Brett McInelly occurred at a moment of gloom, when RAE's publisher, AMS Press, collapsed. Brett now had an orphaned volume of RAE. I had helped to find several of the early career scholars, including international ones, who contributed to this volume and nurtured along their articles by finding competent peer reviewers. When Brett relayed the dolorous news, he noted that a few of the contributors were counting on this publication for their tenure application files. Furthermore, there was a piece by Bob Tennant, an active and industrious scholar in the field, who had passed away during the publication process. Brett and I flew into action, motivated by a sense of rescue, of not wanting this project to fall to pieces to the disappointment of all. It is highly satisfying to report that after some effort to find a suitable publisher and hard work to meet new specifications, we were able to place the entire volume and the book is now published.

\author{
Kevin Cope \\ Louisiana State University, Baton Rouge \\ Editor, 1650-1850: Ideas, Aesthetics, and Inquiries in the Early Modern Era
}


None of the Grimms' Fairy Tales begins with "once upon a time there was no religion,” but that version of the famed storytelling brothers' standard opening describes long-eighteenthcentury studies at the time of the founding of Religion and the Age of Enlightenment. To be sure, the carousel of then-current scholarly approaches, whether war-weary cultural materialism or the various predecessors of what we now call gender studies or the sprouts of ecocriticism or plain old multi-disciplinarity, circled around the study of faith, belief, theology, and ritual. Occasionally some retiring deconstructionist would notice that Dr. Johnson now and then muttered a few prayers. Yet scholars, most of whom worked in public institutions in which god-populated religion had been secularized into tame, softly anthropological "religious studies," remained reluctant to focus on the history of faith. This awkward timidity presented an opportunity: who would put reputation, career, and perhaps sanity at risk to recognize the inescapable fact of the religiosity of the Enlightenment- to admit that almost everyone in the long eighteenth century either practiced a religion or articulated religious ideas or at least paid lip service to angels, demons, and, in sum, everything in view of St. Peter's gate?

In this context, and shortly after the turn of the new millennium, conversations began concerning the possibility of a journal that would take an unrepentant interest in the purveyors of penitence: in the myriad manifestations of religious conviction during an era that prided itself on revising or updating almost everything. Long an enthusiast for anything comfortably arcane - for culturally cordial productions such as emblem books, travel journals from the holy land, or extracts from complex religious controversies, but not for impolite zombies, nuisance ghosts, or anything ghoulish-AMS Press impresario and telephone aficionado Gabriel Hornstein called me and likely a thousand others seeking advice about starting a journal limited to religion but open to any and all scholarly approaches. The response: an almost universal enthusiasm from those who hoped to be at long last liberated to talk about this most unexplored of topics. The nominee for the job: Founding Editor Brett McInelly, already established as the most ecumenical of scholars owing to his renowned studies of early Methodism, his placement in an American church-affiliated institution, and his reputation as the freest of thinkers. The rest is - if we dare use the " $\mathrm{e}$ " and "s" words - an academic version of eschatological and soteriological history. A veritable "field of folk" contributed study after study on fascinating and occasionally offbeat topics while circulation swelled. Now RAE leads the way, if not yet into the spiritual world, then into the slightly spiritualized electronic zone as it takes on a new title and new life as the premier online journal in its field!

\section{Brett C. McInelly \\ Brigham Young University \\ Editor, Religion in the Age of Enlightenment Senior Editorial Advisor, Studies in Religion and the Enlightenment}

While attending the South Central Society for Eighteenth-Century Studies' annual conference in New Orleans in 2008, I was approached by the late Gabriel Hornstein, president of AMS Press, about launching a scholarly annual devoted to the study of religious topics during the Long Eighteenth Century. Despite my trepidations taking on such a project, I enthusiastically accepted his invitation to serve as editor, believing that such an annual was long overdue. I was also aware of AMS Press's long-standing commitment to academic publishing generally and eighteenth-century studies specifically and that that commitment, coupled with some 
sweat equity, could make such an annual a reality. The culmination of my conversation with Gabe was Religion in the Age of Enlightenment (RAE), the first volume of which appeared in 2009. The fifth and final volume appeared in 2015. Volume 6 was press ready when AMS shut its doors in early 2017 following Gabe's passing, and I'm pleased to report that the majority of the articles that were originally included in volume 6 , along with a handful of other articles slated for a later volume, recently appeared in a collection edited by myself and Paul E. Kerry entitled New Approaches to Religion and the Enlightenment (Fairleigh Dickinson University Press, 2018). I'm equally delighted to see the spirit of $R A E$ revived in Studies in Religion and the Enlightenment, and I thank Samara Cahill and Nanyang Technological University for their efforts in continuing to provide a forum for scholarly conversations about the provocative and compelling ways in which religion and enlightenment intersected and informed the other during the Long Eighteenth Century.

I would be remiss if I did not take this opportunity to express my heart-felt thanks to $R A E$ 's editorial board for years of dedicated service and support as well as the two outstanding individuals who served as book review editors, Kathryn Duncan and Samara Cahill. I express my appreciation to the contributors whose work ultimately defined RAE and to Melvin J. Thorne and Suzy Bills of the Brigham Young University Faculty Publishing Service and their team of student editors for their help with copyediting, design, and the layout of the journal. Finally, I thank Gabe Hornstein and AMS Press for their commitment to $R A E$ and eighteenth-century studies. 